\title{
INTERNATIONAL CORPORATE GOVERNANCE RESEARCH: SOME CONTEMPORARY INSIGHTS*
}

ŚLĄSKI

PRZEGLĄD

STATYSTYCZNY

Nr 18(24)

\author{
Sascha Moells, Vladena Prysyazhna \\ Philipps University of Marburg, Germany \\ e-mail: prysyazv@staff.uni-marburg.de
}

\begin{abstract}
(C) 2020 Sascha Moells, Vladena Prysyazhna
This work is licensed under the Creative Commons Attribution-ShareAlike 4.0 International License. To view a copy of this license, visit http://creativecommons.org/licenses/by-sa/4.0/
\end{abstract}

Quote as: Moells, S., and Prysyazhna, V. (2020). International corporate governance research: some contemporary insights. Śląski Przegląd Statystyczny, 18(24).

DOI: $10.15611 /$ sps.2020.18.21

JEL Classification: C21, G34, M14

In recent years there has been growing interest in empirical research on corporate governance, accounting and finance, as the number of studies published in this field is continuously increasing. However, one of the most severe limitations of the existing studies is the consideration of specific topics only from a national perspective. In particular, this problem arises in the research on corporate social responsibility (CSR). Empirical studies on the determinants affecting firms' propensity to publish non-financial information about their environmental and social activities (the so-called CSR-reporting) and the scope of the information disclosed, are typically based on a rather small sample of companies from one specific country (in particular the USA). However, due to country-specific economic and regulatory environments, the empirical results derived from such national studies cannot be generalized and thus allow only for an inference limited to the country under investigation. In order to extend the applicability of the empirical results, conclusions must be derived based on an international sample of firms. The few authors conducting international comparative analyses on CSR predominantly compare directly the subsamples of firms from different countries. However, companies operating in different macroeconomic and regulatory environments have systematically different company-specific characteristics. For example, US companies are systematically larger and more profitable compared to German ones.

* 25th Scientific Statistical Seminar „Marburg-Wrocław”. Gollhofen, 23-26 September 2019. Extended abstract. 
Hence, these two subsamples of companies cannot be compared directly. Accordingly, an appropriate methodology must be applied in international Nr 18(24) comparative studies that allows for reweighting observations (i.e. companies) according to their observable characteristics. This study claims that applying this kind of methodology would allow scholars to make consistent estimations with regard to international samples of companies, and thus facilitate empirical research on corporate governance, accounting and finance.

\section{References}

Abadie, A. et al. (2004): Implementing Matching Estimators for Average Treatment Effects in Stata, in: The Stata Journal, Vol. 4 (3), pp. 290-311.

Abadie, A. \& Imbens, G.W. (2011): Bias-Corrected Matching Estimators for Average Treatment Effects, in: American Statistical Association Journal of Business \& Economic Statistics, Vol. 29(1), pp. 1-11.

Aguilera, R.V. \& Jackson, G. (2003): The Cross-National Diversity of Corporate Governance: Dimensions and Determinants, in: Academy of Management Review, Vol. 28(3), pp. 447-465.

Clarke, T. (2017): International Corporate Governance: A Comparative Approach (2nd ed.). London and New York: Routledge.

Devinney, T.M., Schwalbach, J. \& Williams, C.A. (2013): Corporate Social Responsibility and Corporate Governance: Comparative Perspectives, in: Corporate Governance: An International Review, Vol. 21(5), pp. 413-419.

Ioannou, I. \& Serafeim, G. (2012): What Drives Corporate Social Performance? The Role of Nation-Level Institutions, in: Journal of International Business Studies, Vol. 43, pp. 834-864.

Ioannou, I. \& Serafeim, G. (2017): The Consequences of Mandatory Corporate Sustainability Reporting, Working Paper 11-100, Harvard Business School.

Larcker, D.F. \& Tayan, B. (2016): Corporate governance matters: A Closer Look at Organizational Choices and Their Consequences (2nd ed.), Pearson FT Press: Upper Saddle River.

Okpara, J.O. \& Idowu, S.O. (2013): Corporate Social Responsibility Challenges, Opportunities and Strategies for 21st Century Leaders, Berlin, Heidelberg: Springer-Verlag.

Shleifer, A. \& Vishny, R. (1997): A Survey of Corporate Governance, in: The Journal of Finance, Vol. 52(2), pp. 737-783.

Witt, M.A. \& Redding, G. (2012): The Spirits of Corporate Social Responsibility: Senior Executive Perceptions of The Role of The Firm in Society in Germany, Hong Kong, Japan, South Korea and the USA, in: Socio-Economic Review, Vol. 10, pp. 109-134.

Keywords: corporate governance systems, corporate social responsibility reporting, average treatment effect. 